\title{
THE INFLUENCE OF EXCHANGE RATE REGIMES ON ECONOMIC GROWTH: A MULTICOUNTRY EXAMINATION
}

Rebecca Abraham, Nova Southeastern University, U.S.A.

Ravi Chinta, Nova Southeastern University, U.S.A.

Zhi Tao, University of Alaska at Anchorage, U.S.A.

dx.doi.org/10.18374/JIFE-21-1.1

\begin{abstract}
This paper evaluates the ability of exchange rate regimes to influence economic growth. Exchange rate regimes for 186 countries were classified into four categories. For the full sample, exchange rate regimes increased economic growth although inflation reversed the increase in economic growth, both for the full sample, and for developed countries. For developing countries, during the historical time period, all of the classifications increased economic growth with increasing flexibility of the exchange rate regime. For the modern period, developed countries displayed similar significant relationships, as did high, middle, and low income countries, small island states, and inland states.
\end{abstract}

Keywords: exchange rate regime, economic growth, developing countries, developed countries, fixed exchange rate, flexible exchange rate 